\title{
PERSONAL LOAN COMPANIES IN POLAND: DOES EMPIRICAL EVIDENCE JUSTIFY REGULATORY TRANSITION?
}

\author{
Andrzej Cwynar, Wiktor Cwynar, Kamil Wais, Radoslaw Parda*
}

\begin{abstract}
We surveyed representative sample of 1,004 adult Poles to check the extent to which they distinguish among the entities operating in the market for personal loans in Poland, how they perceive loans and lending entities, and what is their knowledge on lending/borrowing issues. Particularly, we were interested in getting the insight into the fragment of the market that is operated by personal loan companies, with special emphasis on the profile of the average (statistical) borrower. Our examination was motivated by the controversies surrounding the law amendment started in Poland in 2015 in order to regulate the fraction of the consumer credit market represented by personal loan companies. By utilizing logistic and multivariate linear regression models with variables obtained from our survey, we tested whether the legal reform was well-informed and well-addressed. We found that Polish households have serious problems with distinguishing various entities that provide loans to private individuals and that such problems manifest even greater problem of material shortcomings in Poles' debt literacy. We also evidenced low public trust to lending entities, particularly to loan companies. In the light of the findings the law amendment is well-grounded, however it should be supported by actions aimed at enhancing households' financial literacy.
\end{abstract}

Keywords: personal loan companies, market for personal loans, lending regulations, public trust in lending entities, debt literacy

JEL Classification: G21, G23

\section{Introduction}

The activity of loan companies is considered controversial. On the one hand, they fill the niche on the consumer credit market by supplying low-amount loans with short maturity periods (unprofitable in typical commercial bank business model). Hence, they reduce the banking, and more broadly, financial exclusion. On the other hand, it is argued that since such loans are irrationally, even improperly costly, along with the fast granting procedure they can pose a threat to the consumers unaware of their imbedded properties leading them to the edge of the financial illiquidity and the spiral of debt. In the institutional setting in which only the loans granted by the banking sector are fully regulated such controversies are understandable. This was the case of Polish personal loans market before the end of 2015. Formerly, the market was fragmented into two broad segments: regulated banking sector (represented by commercial banks, including cooperative ones, and social

\footnotetext{
* Andrzej Cwynar, University of Economics and Innovation in Lublin, Poland (cwynary@gmail.com); Wiktor Cwynar, University of Economics and Innovation in Lublin, Poland (wiktor.cwynar@gmail.com); Kamil Wais, University of Information Technology and Management in Rzeszow, Poland (kamil. wais@gmail.com);

Radoslaw Parda, Leadership Consulting, Poland (radekparda@gmail.com).
} 
credit unions), and unregulated non-banking sector comprising not only typical loan companies, but also social lending firms, pawnshops (loan offices) and parabanks as well as non-official lending activities. This led to a situation in which some firms abused their status and as the result of that they were charged with fraud (e.g. in the Amber Gold scandal the parabank defrauded about PLN 850 million $^{1}$ ). The lack of the precise definition of such terms as "loan company" or "parabank" eventuated in that the negative implications of the scandals were also experienced by the legitimate lending businesses - transparent and adhere to high standards. Those events motivated the regulation authorities to complete the chronic process of the legal adaptation to the new, more complex situation in the market for consumer loans. Ultimately the updated law was partly introduced at the end of 2015. However, the opinions on the law amendment are mixed.

We investigated representative sample of 1,004 adult Poles to study their opinions and knowledge on the selected issues concerning the consumer credit market and that way to get additional insight into the motives and premises of the lending law modernization in Poland. We assumed that even though the necessity of the amendment seems to be indisputable, some of the arguments justifying the reform the regulator refers to may be considered somewhat questionable and thus some of the regulatory shifts may not be well-informed. To verify the hypothesis we formulated the following research questions which at once reflect the objectives of the article: (1) What is the degree to which consumers accurately recognize various entities which can grant loans to them? (2) What is the perception of and the attitude to loans as well as to different subjects operating in the lending market (banks, credit unions, loan companies, parabanks etc.)? (3) What is the profile of the statistical borrower on the consumer credit market (with special emphasis on the loan companies' clients)? (4) What is the financial literacy of the borrowers, particularly with regard to lending/borrowing issues? In search for the answers to the queries we were particularly interested in the conclusions concerning the loan companies since they represent the biggest and the fastest growing portion of the non-banking consumer credit market in Poland.

Our work can contribute to the existing body of knowledge on the lending market in at least three ways. Firstly, the studies in which other authors demonstrate the situation on the consumer credit market in Poland were issued in the period preceding the legislative works in the Polish Parliament and were based on 2012-2013 data, while our study was conducted in the middle of 2015. Secondly, it is argued that because of some flaws of the newly implemented law, there will be additional amendments in the future. If so, then they should be well-grounded and refer to the latest findings and our investigation delivers such. Thirdly, even though Poland was the last large European country which regulated the non-banking lending market, still there are economies without such regulations (e.g. the Czech Republic). The observations made in our study may be of a value for the regulators and their advisory bodies in such states and help them to design the legal transition process properly and conduct it effectively.

The remainder of the paper is organized as follows. In Section 2 we make brief literature review. Section 3 is the methodological part in which we present utilized research tools, data and models. The empirical results and discussion on them are demonstrated is Section 4. Last section concludes the article.

1 Currently 100 EUR $=424$ PLN. 


\section{Literature Review}

\subsection{Scope of the survey and terminological issues}

It is not the role of the article to make a depth survey of the international findings on personal loan companies. Rather, it is intended to scrutinize the specificity of the current state of the sector in Poland and the recent legislation shift experienced by it, as well as to indicate some lessons that can be learned from this by policy makers in the countries in which the regulation of the sector is still ahead. Thus, we refer to the foreign literature only when dealing with key issues. We believe that the diversity of solutions regarding personal lenders in various jurisdictions - many times incomparable ones - justifies our view that such comprehensive cross-country analysis of the personal lending market would be unreasonable, at least at the currently limited access to necessary data. The aforementioned variety of the ways in which the sector can be structured and regulated results - among other things - in different market segmentation and different names attached to the segments which are unique for some countries. This is the case of Poland since the label "parabank" - introduced not only to informal, but also to professional language - has got different meaning than abroad. Moreover, there is no official or generally accepted definition of parabank in Poland. The interpretations of the term are varied and in some sources the category with this name - negative in its overtone - unfairly encompasses also personal loan companies. In our study we followed the interpretation formulated by the Polish Financial Stability Committee (National Bank of Poland, 2012) in which parabank was defined as the institution operating out of respective regulations and extending loans on the basis of money deposited by its clients, while not being the bank. Such clarification is accepted not only by the personal loan companies industry, but also by independent bodies and institutions (see e.g. the Office of Competition and Consumer Protection, 2012, PwC, 2013). Additionally, the term "payday loans" - attributed to loan companies and generally accepted abroad, at least in Anglo-Saxon world, and utilized also is our article - is not a perfect counterpart of the small amount, short-term, usually higher-cost lending provided by personal loan companies active in Poland (in the article we assumed that the counterpart of the term "payday loan" is Polish neologism "chwilówka", used to characterize the loans of extremely small amounts that are granted extremely fast). As the result, some research issues we were interested in were hardly comparable in the international setting.

\subsection{Consumer credit market in Poland: overview}

The latest edition of "Monitoring of Banks" (Central Statistical Office, 2015) informs that the total value of the consumer loans granted by them to households reached PLN 123,491 million at the end of 2014 including instalment loans (car loans among them). It is estimated that the value of households' liabilities due to banks (including housing real estate loans) totalled approximately PLN 600,000 million in 2014 (Luczak, 2015; National Bank of Poland, 2015). Personal financial obligations in relation to other institutions operating in the market are considerably lower: due to social credit unions PLN 10,000 million, due to loan companies PLN 4,000 million (PwC, 2013). This means that the segment of the market served by loan companies constitutes only about $3 \%$ of its 
total value. However, small amount of the average loan results in that the number of loans they grant is around $50 \%$ of those taken out of banks (Białowolski, 2012).

The studies conducted so far report that even half of Polish households may be financed by different kinds of credit (the Credit Information Bureau and the Kronenberg Foundation, 2014). Yet, only 3-4\% of them acknowledge that they are clients of loan companies and, interestingly, the percentage is lower than the share of households that admit they borrow money outside the official market (PwC, 2013; the Credit Information Bureau and the Kronenberg Foundation, 2014; Czapinski and Panek, 2015). All of those numbers mean that the fragment of the market which is operated by loan companies is still relatively small, but it brings serious socio-economic effects.

The numbers describing this particular section of the market are both incomplete and imprecise since - as distinct from banks - loan companies do not have rigorous reporting obligations. Therefore, even the exact number of firms active in the market is unknown. According to some sources it may reach even 20,000 (Luczak, 2015). However, the number of those that have country-wide coverage is about 100 (Szelagowska, 2015). Many of them are affiliated in one of the industry organizations - the Association of Loan Companies and the Conference of Financial Companies in Poland. It is estimated that the employment in the market sector is about 5,000 (including agents and brokers) while the number of clients may reach 1.4-1.5 million (Kaczmarski, 2015; Zwiazek Przedsiebiorcow i Pracodawcow, 2015).

In Poland, first loan companies entered the market at the turn of 20 th and $21 \mathrm{st}$ Century. On its supply side, the sector is segmented. There are three distinct business models used by the companies delivering personal loans: (1) home lending, (2) branch / outlet lending, (3) online lending. From analytical perspective such segmentation is significant since the adapted business model determines such issues as average loan amount and duration, cost structure (also for the borrower) and creditworthiness evaluation procedure. The differences concerning such parameters may matter for the ultimate results of the new regulations introduced lately in Poland since the likely impact of the law amendment on the above-mentioned segments will not be the same. We refer to the issue later in the article.

Despite these differences, the personal loan companies provide their clients on average - with smaller amounts of money for shorter periods in comparison with banking loans. It is argued that banks are not interested in loans having such properties because of high fixed (overhead) costs in relation to small amount of the loan along with increased risk (as compared to the profile of the standard bank client). Yet, a class of potential borrowers looking for such micro financing of their personal needs still exists. They are represented by those having the so called junk contracts, seasonal work, odd job, but also the independent professionals and non-official workers. Such occupational classes are exceptionally subject to banking exclusion when looking for borrowing. Hence, it seems that personal loan companies should not be considered a competition for banks as they serve different segment of the market.

One of the key points in the debate around the lending law modernization in Poland was the loan companies' pricing policy. The issue is controversial since, on the one hand, the loan cost incurred by their clients - being high compared to banking loans - arouses suspicion that the companies take advantage of their clients exhibiting inelastic demand. Thus, such reasoning called for more protection and resulted in modified regulation concerning the pricing policy 
of loan companies (price limits are to be introduced in March 2016). On the other hand, a part of the respective literature indicates that higher price of money borrowed in a loan company compared to bank - can be economically justified, at least to a degree, for two main reasons. Firstly, the price premium results from the same reasons for which banks are not interested in the market segment: high fixed costs combined with larger-than-average credit risk (PwC, 2013). Secondly, the price ultimately depends on the capital cost loan companies must pay which is higher than for banks as they get it through deposits (Fundacja Republikanska, 2013). Some authors estimate those costs as $0-4 \%$ in banks and $5-30 \%$ in loan companies since they must raise funds in financial markets (Ciesla, 2014). Moreover, loan companies market in Poland is currently competitive with hundreds of firms striving for market share gains which excludes disproportionately high prices. Instead, they try to build good relations with their clients and this is impossible at predatory pricing practices (Bialowolski, 2012; Zwiazek Firm Pozyczkowych, 2013). Bialowolski (2012) indicates that profit margins which are lower in loan companies sector than in banking sector confirm such assertions. Additionally, PwC (2013) reports that most of the studied loan companies "provide its customers with fair and clear information on the costs and other terms and conditions of the loans" (p. 5).

\subsection{Current regulatory shift}

The new act altering the financial market supervision rules and some other regulations important for personal loan companies, that entered into force on October $11^{\text {th }}, 2015$, puts them in face of new requirements. Firstly, the only legal forms in which they can run their activity are joint-stock company and limited liability company. Secondly, share capital must not be lower than PLN 200,000 and must be paid in cash. Thirdly, the Polish Financial Supervision Authority gains additional rights in relation to loan companies. Fourthly, it sets maximum interest for delay in repayment (6 times Lombard rate of the National Bank of Poland, per annum) and also introduces special formula allowing for the estimation of the maximum non-interest costs of loan. This is one of the most controversial aspects of the law amendment since many professional bodies were arguing that it might be counter-productive. For example, PwC (2013) points out that the usefulness of annual percentage rate (henceforth, APR) - which includes all loan costs, including those non-interest ones - as the tool for comparing costs of various loans is questionable. They conclude that the statutory limits imposed on APR may result in removing some products from the market. Majority of interested parties think that this will concern mainly payday loans as they will become unprofitable under the new legal regime. Henceforth, a fraction of borrowers will be forced to apply for loans that are inadequate for them: characterized by larger amounts and longer durations. Consequently, this may result in even more indebtedness in relation to their incomes and thus jeopardize their solvency. Alternatively, they will be pushed into the non-official lending relations that are evidenced to be the fragment of the lending market in which the likeliness of the debt spiral is extremely high (Bialowolski, 2012). Finally, the new act does not implement the register of personal loan companies, although it was initially planned in the draft law. Perhaps, this is the most significant weakness of the law amendment as the representatives from all walks of life evaluated the idea positively. The significance of credible information availability that leads to increased transparency in the market for personal loans was raised by the World Bank in its Global Financial Development Report (World Bank, 2014). The report - as many 
other sources - warns also that the policy makers' decisions should be well-balanced: they should result in strong and effective regulations aimed at consumer protection on the one hand, and better-informed market participants along with healthy competition on the other hand. Those who advocate such view point out that the overregulation may be harmful for the borrowers since it can lead to credit availability restrictions: more constrained access to formal loans because a part of the market may get unofficial or be driven offshore.

\section{Methodology}

We designed questionnaire consisting of two general parts: (1) the set of 22 closed and semi-open questions and (2) the knowledge test containing 12 "true / false / don't know" queries. Then the survey was fielded among 1,004 Poles at the age of 18 or more over the period June $16^{\text {th }}-$ July $3^{\text {rd }}, 2015$. The sample was representative and investigated with CATI methodology. We partnered with professional market research firm, BioStat, to conduct the survey.

The empirical examination was split into several parts and was based on the responses to selected survey queries (a part of the empirical material was not used in the paper because it was intended to serve other scientific purposes).

Firstly, we analysed the extent to which respondents distinguish among various entities extending personal loans. In this step, we used simple analytical tools based on the respondents' answers, without utilizing the regression procedure. Secondly, in our research we were interested in getting the insight into the factors responsible for the reliance to (confidence in) personal loan companies as compared to banks and other institutions providing loans to private individuals. To do that, we utilized logistic regression models with the reliance being the dependent variable and selected sociodemographic characteristics, as well as other potentially explanatory factors obtained from our survey, used as the independent variables. We were able to observe reliance to various entities granting personal loans since fourteenth question of the survey was aimed at scrutinizing it. The dependent variable was recoded as " 0 " if the respondent's answer concerning the confidence in the entities granting loans to private individuals was "no confidence at all", and " 1 " if the respondent declared any other level of confidence on the 5-point scale provided in the questionnaire. In the preliminary models we checked various variables that we hypothesized to be statistically significant explanatory variables. Additionally, the knowledge test scores (henceforth "objective knowledge") were also used as the independent variables. If any of these variables turned out to be statistically insignificant, it was removed from the final models. Thirdly, our investigation was also aimed at the identification of respondents' debt literacy and factors determining it. To achieve the goal, we used the knowledge test scores and built multivariate linear regression model with test scores as numerical explained variable testing the explanatory power of selected demographic and other (qualitative) sample characteristics (some of the variables were also included in the logistic models). To be useful in the analysis, the knowledge test responses were recorded according to the correctness criterion and translated into adequate points (plus 1 for correct response, minus 1 for incorrect response, no points for "don't know" response). The sum of points for responses to particular queries, gathered within entire sample, was considered the synthetic gauge of the respondents' knowledge on lending/borrowing issues. Consequently, we obtained distribution of the objective knowledge results close to normal distribution with slight dominance of incorrect responses (the worst respondent's score was 
minus 12 while the best one's plus 10 , with median at minus 1 and mean at minus 1.22 ). Such distribution allowed for credible differentiation of the sample in terms of the objective knowledge concerning issues associated with loans. To ensure the comparability of our findings with the results obtained by other authors, including classic work of Lusardi and Tufano (2009), we complemented the examination of debt literacy by asking the respondents about their self-assessment of the knowledge concerning fundamental concepts related to debt (hereafter "subjective knowledge"). In fact, what we examined was debt knowledge rather than debt literacy since the latter is considered as "capacity of individuals to make simple financial calculations" concerning debt (Disney and Gathergood, 2011, p. 1). Fourthly, we were also curious about the profile of the statistical personal loan company's customer, however, our study showed that the number of such respondents is too low to allow for the credible, formal interference.

The details concerning utilized models are depicted in the Appendix.

\section{Results and Discussion}

\subsection{Knowledge of the entities providing personal loans}

In our survey we asked two questions allowing us to get an insight into the respondents' discernment concerning entities providing personal loans (we decided to forgo the detailed presentation of the survey questions because of the article length limits). We perceive the obtained results as evidencing that the level of knowledge as to where private individuals can borrow money is at most moderate. Although almost all surveyed people indicated bank as the entity that extends personal loans, only $43 \%$ of them pointed also credit unions. Interestingly, the awareness of the online lending channel is still low. This holds not only for social lending platforms $(11 \%$ of respondents knew that they could borrow money that way), but also for the loan companies that operate in the online segment compared with traditional one ( $28 \%$ versus $45 \%$, respectively).

The key finding is, however, that it is unclear for the respondents where the dividing lines run - the lines that divide the personal loans market on its supply side. It manifested itself mainly in confusing parabanks with loan companies and other entities by large portion of surveyed subjects. As opposed to parabank, the personal loan company lends money on the basis of its own capital - not through deposits made by its clients. Even though one-third of the respondents correctly associated parabanks with bank-like institutions still not being legitimate banks, only $10 \%$ rightfully noticed that they are institutions that not only grant loans, but also take deposits. Moreover, for $16 \%$ of respondents parabanks mean personal loan companies and for $13 \%$ - payday loan companies. Even social credit unions were confused with parabanks by some investigated people (7\%). Such observations should not be considered a surprise as not only loan companies, but also credit unions are considered "shadow banks" even by professional bodies and the authors of scientific articles, and one can reasonably assume that for majority of Poles the difference between parabank and shadow bank is unclear or they do not know the nature of the difference. PwC (2013) rightly notices that even in more developed economies the differences as to the meaning of such terms as "shadow bank" still remain.

We believe our evidence suggests that the effective regulatory transition encompassing entire personal lending market should include actions aimed at obtaining - at the end of the process - better-informed market participants. This could be achieved both 
by the introduction of precise and official definition of the entities newly covered by the regulation (i.e. personal loan companies) and by conducting legitimate register of such entities. Unfortunately, none of these were implemented. The Polish Consumer Credit Act includes merely an ersatz of the personal loan company definition in the form of a catalogue of exclusions that is more useful in understanding what personal loan company is not than what it is.

\subsection{Public confidence in entities providing loans to private individuals}

Our survey shows that $67 \%$ of respondents do not trust the entities that grant personal loans. On the basis of gathered responses we computed indices of reliance to various types of personal lenders (with possible values within the scale from 1 to 5 , inclusively). As expected, banks were rated substantially higher than other entities (3.23 points), including credit unions (2.06 points). The indices estimated for loan companies (both segments), social lending and parabanks were alike (between 1.31 for traditional loan companies and 1.43 for online loan companies). Such results mean that even the reliance to banks is at most moderate.

We made a number of interesting observations concerning the reliance to loan companies and other entities providing loans to private individuals on the basis of our survey. Firstly, we found that, in general, the models of reliance to loan companies slightly differ from the model of reliance to banks in the sense that the sets of key factors determining trust are somewhat distinct in each case. The difference is mainly concerning the presence of the general trust in the regression model estimated for banks, and - to a lesser degree - the level of educational attainment statistically significant in the model for personal loan companies (traditional segment). Secondly, subjective factors (such as general trust of the respondents and their attitude to loans) were evidently more significant for the explanation of reliance to banking sector entities (banks and credit unions) than demographic or other objective factors. The opposite was evidenced in the non-banking entities models, including personal loan companies. This means good news for such companies since they can base their lending offer on easily measurable and quantitative factors and precisely address their products to appropriate groups of potential borrowers. Thirdly, both models estimated for personal companies - traditional and online, respectively - gave similar results, with the difference concerning the age, relevant in the model for online segment companies, as expected (our investigation confirmed that the trust is the negative function of age). Fourthly, two independent variables can be considered especially important for the explanation of reliance to the entities extending personal loans since they were found statistically significant in majority of the investigated models. There are (1) prior borrowing experiences with the respective entity (positively affecting the trust in all models, except for the one estimated for parabanks), and (2) trust towards lending entities (with the explained variable positively dependent on it in all models). Finally, we found also that the knowledge on lending/borrowing issues is almost irrelevant for explaining trust in the entities active in the consumer loans market, which was a surprise to us.

Some supplementary interesting conclusions can be withdrawn from the odds ratio values. Our study shows that they do not differ importantly among all estimated models in regard to the trust towards lending entities (except for the model for banks in which the ratio is markedly lower). This seems to be understandable given the general nature 
of the survey question underlying the variable. Differently, we noticed evident disparities among the odds ratios for the variable marked as "Previous customer experience with the respective lending entity". Essentially, they were lower for the entities representing banking sector compared to personal loan companies, with the highest value - 5.03obtained for traditional-sector loan companies (it was 1.95 for banks, by contrast). This means that the chance of having trust to such companies is more than five times higher for those who formerly borrowed money from them compared to those who did not. This is crucial finding as it suggests that a kind of a psychological effect, similar to the fear of unknown, can be at play, being reinforced by stereotypical - and sometimes unfair - opinions concerning personal loan companies. Our findings can imply that the actual experience with them removes such barriers substantially. The trust models also show that the chance of having confidence in personal loan companies (in both segments) importantly increases for those who seek the information concerning loans in the Internet. Noticeably, the factor was insignificant in other models (it was replaced by the advices of the family members in the model for banks with the odds ratio as high as 4.63).

\subsection{Debt knowledge}

Our findings concerning debt literacy are generally coincident with the conclusions of other Polish empirical evidence (e.g. the Credit Information Bureau and the Kronenberg Foundation, 2014, as well as Instytut Wolnosci and Raiffeisen Polbank, 2014, among other studies conducted in Poland so far). We found that majority of respondents (61.3\%) had moderate knowledge on the issues related to credits and loans. Importantly, the class of respondents exhibiting moderate knowledge not only dominates, but also exceeds $50 \%$ in almost all demographic cross-sections.

Out of all independent variables, selected preliminarily in the regression model utilized by us to scrutinize factors determining the knowledge concerning lending/ borrowing issues, some turned out to be statistically insignificant. Interestingly, this is the case of the variable denoted as "Subjective knowledge". From previous Polish investigations we knew that Poles tended to overestimate their financial literacy (our survey confirmed that), yet we expected that there would be at least weak positive and significant relationship between respondents' knowledge and their self-assessment of it. Also, the age was verified to be statistically insignificant. This was to a surprise for us since we assumed that the most experienced (middle-aged) people, yet still keeping up with the high pace of changes in the economic surroundings (including financial market), should be more financially literate compared to other age classes.

The variables identified as statistically significant and hence accepted for the final multivariate regression model are given in the Appendix. All else equal, males have higher knowledge scores than females. Such observation is in line with the international findings of the OECD (Atkinson and Messy, 2012) showing that in almost all examined countries women are less financially knowledgeable than men (with the differences being particularly substantial in Poland, Norway and UK). Indeed, the results may be of high importance since other studies suggest that these are women who usually govern households' budgets in Poland (Deutsche Bank, 2013) and are considered more effective in using money (ING, 2013). This may evidence that in a sense - and for some reasons that deserve deeper consideration - women experience some constraints concerning the access to the financial knowledge. Thus, what we observed calls for customized actions aimed 
at increased financial literacy of women. As suspected, higher level of education plays important, positive role in the model, particularly if one has a Ph.D. degree. Again, the observation is consistent with the international results obtained in the OECD study (Atkinson and Messy, 2012). The same study reports that - in general - higher income leads to higher financial literacy scores. Our investigation confirmed that effect, however, with one noticeable exception. With most common net income per family between PLN 500 and 999 as baseline level, most levels of this variable are also statistically significant but their relationships with the explained variable turned out to be non-linear. People with higher net income tend to have higher knowledge scores, however, with net income level per family member above PLN 2,499 the scores are lower than in the smaller income clusters. This is an intriguing result that can evidence decreased inclination of the wealthiest people to acquire financial knowledge as their material status gives them the sense of safety and thus reduces the motivation to multiply the knowledge concerning personal finance. Yet, we perceive the effect as requiring further formal and more detailed investigation. Another intriguing observation is concerning the impact of the general trust of respondents on their debt knowledge scores. We found that those who do not trust other people are less debt knowledgeable than those who do. We perceive the effect as possibly evidencing a causeeffect relationship or perhaps even more-a kind of a feedback loop or self-feeding mechanism: low trust keeps such people away from the entities granting loans (financial exclusion) which leads to low knowledge concerning them (assuming that personal experiences are crucial for such knowledge) and vice versa (low knowledge reinforces the lack of trust and so on). Yet, in the light of our results presented in Section 4.2, the backflow relationship requires further studies. Finally, our results show that higher knowledge scores can also be explained by the negative attitude to loans in general, however, the pair of variables was also reversely related in the logistic regression model of positive attitude towards loans in general showing that more knowledgeable people are more critical of loans.

\subsection{Loan company customer profile}

Our research allowed us to ascertain that the number of respondents having liabilities due to personal loan companies was 21 ( $2 \%$ of the sample). This observation is somewhat surprising in the light of the personal lending industry announcements we referred to in Section 2 of the article. According to them the population of people borrowing money from loan companies is about 1.5 million. Raw estimates assuming that the number of adult Poles is approximately 30 million suggest that the percentage of population loan companies lend money to should be about $5 \%$. Such disparity was also found in other Polish market research. We perceive it a "stigmatization effect". Even though our respondents were informed about the anonymity of the survey, we think some of them were reluctant to report their debt due to a loan company because of the average perception of such borrowings in the society. The answers to some queries included in our survey may confirm such view. The empirical evidence we gathered shows that $63 \%$ of respondents believe the term "payday loan" has got negative overtone. Therefore, those who borrow money from personal lenders, may be concerned about the reception of their decision to do that by the social environment and, ultimately, hide it.

The small number of personal loan companies' customers identified in our research did not allow for depth analyses of the demographic characteristics of the sub-sample. As a formality we can say that it comprised almost the same number of women and men 
(11 versus 10, respectively), mainly aged 31 years and more (18 respondents). However, these and other characteristics are significantly distorted by the distribution of demographic features in the entire sample (for example 10 loan companies' clients - out of all 21 reported secondary educational attainment; yet, the respondents with such education had almost $40 \%$ in the entire sample). Thus, we resigned deepened investigation of the loan company customer profile.

\section{Conclusions}

We believe the enhanced regulation of the consumer credit market in Poland implemented in 2015 was essential both for the business entities operating in the market and for their customers. The empirical results gathered by us confirm such view even though they illustrate solely the situation on the demand-side of the market. The results suggest that Poles have serious difficulties in distinguishing various institutions extending loans to private individuals. They recognize banks, yet other types of entities active in the market - even social credit unions - are often confused by them. We perceive the finding a manifestation of a greater problem - i.e. at most moderate knowledge of Poles in regard to debt and borrowing. The finding is worrying since the inability to make a distinction among the properties of different lending entities can result in sub-optimal and even precarious contracts signed without full understanding of them. On the other hand, low knowledgeable customers can be responsible for some negative effects experienced by supply-side market participants. For example, our study showed that considerable portion of the respondents confuses personal loan companies (and even credit unions) with parabanks - lending institutions associated with abuses and fraud against their clients. Hence, the legitimate personal loans companies adhering to high standards and good practices can be adversely impacted by such misperception. All of those findings confirm the need of some institutional actions enhancing the availability and credibility of the information concerning the entities that can grant personal loans, apart from dedicated educational programs we refer to later in the conclusions. Such actions could take the form of the official register of legitimate personal loan companies announced and conducted by a supervisory body (in the way similar to the standards known from the banking sector). Unfortunately, even though the draft of the law amendment contained such proposition, it was removed from the ultimately introduced version.

The study allowed us to learn some lessons concerning the way Poles perceive lending entities in general and personal loans companies in particular. From the findings we can conclude that the public confidence in the institutions that grant loans to private individuals is rather low (with trust indicators estimated for personal loan companies substantially lower than for banks) and that the attitude towards loans is negative on average. However, we also found that the small fraction of respondents who formerly borrowed money from personal loan companies differs from other respondents in regard to their trust in such companies. This could be interpreted as evidencing positive experiences in relation to personal loan companies and breaking the stereotypical perception of them. However, such assertion may not be sufficiently grounded, since the number of the respondents who reported to be clients of personal loan companies was only 21 in our study. Thus, this observation deserves further investigation focussed on personal loan companies' clients. In the context of the broader discussion concerning the regulatory shift experienced by Polish consumer credit market in 2015 the confirmation of our results would reduce, 
at least partly, some controversies regarding allegedly predatory and ruthless actions of personal loan companies in general (without belittling the importance of the concerns about abusing customers by some firms).

Our empirical evidence also confirmed at best moderate debt knowledge of Poles found in previous studies of other authors. The questions we asked to verify what they know about debt covered broad range of facets concerning personal loans market, its legal framework and typical loan parameters. The results allowed us to make both general and particular conclusions that are key for the adopted research questions. If we assume that low financial literacy in general, and debt literacy in particular, can pose a threat to private individuals applying for personal loans (resulting in potential abuses accompanying the information asymmetry), then we think that the risk of such threat could be controlled - at least partly - by the involvement of the supervisory/regulatory body through a policy aimed at getting more informed borrowers, and not necessarily by direct interventions in loan pricing (i.e. price limits) which can fail in the situation in the market, as evidenced by the experiences of other economies. Moreover, the empirical evidence helped us to identify those socio-demographic groups that deserve special educational treatment (both in its intensity and customization).

\section{Appendix}

Tables A1 | Logistic Regression Results

\begin{tabular}{|l|c|c|}
\hline Statistically significant coefficients in the model & Odds ratio & p-value \\
\hline $\begin{array}{l}\text { Place of living: city: 500,000 residents or more } \\
\text { - baseline level: village }\end{array}$ & 0.56 & 0.072 \\
\hline $\begin{array}{l}\text { Previous customer experience with banks: yes } \\
\text { - baseline level: no }\end{array}$ & 1.95 & 0.003 \\
\hline $\begin{array}{l}\text { Considering opinions of others: no } \\
\text { - baseline level: yes }\end{array}$ & 0.46 & 0.002 \\
\hline $\begin{array}{l}\text { General trust towards others: no } \\
\text { - baseline level: yes }\end{array}$ & 0.58 & 0.016 \\
\hline $\begin{array}{l}\text { Trust towards lending entities: no } \\
\text { - baseline level: yes }\end{array}$ & 0.18 & 0.000 \\
\hline $\begin{array}{l}\text { Seeking information from family: yes } \\
\text { - baseline level: no }\end{array}$ & 4.63 & 0.011 \\
\hline
\end{tabular}

Source: Authors 


\begin{tabular}{|c|c|}
\hline & $\begin{array}{c}\text { Model of trust towards } \\
\text { banks }\end{array}$ \\
\hline (Intercept) & $4.17(0.48)^{* * *}$ \\
\hline \multicolumn{2}{|l|}{$\begin{array}{l}\text { Place of living } \\
\text { - baseline level: village }\end{array}$} \\
\hline town: up to 49,999 residents & $-0.36(0.31)$ \\
\hline town: from 50,000 to 99,999 residents & $-0.23(0.40)$ \\
\hline town: from 100,000 citizens to 499,999 residents & $-0.33(0.37)$ \\
\hline city: 500000 residents or more & $-0.58(0.32)^{*}$ \\
\hline \multicolumn{2}{|l|}{$\begin{array}{l}\text { Previous customer experience with banks } \\
\text { - baseline level: no }\end{array}$} \\
\hline yes & $0.67(0.22)^{* * *}$ \\
\hline \multicolumn{2}{|l|}{$\begin{array}{l}\text { Considering opinions of others } \\
\text { - baseline level: yes }\end{array}$} \\
\hline no & $1.53(0.60)^{* *}$ \\
\hline \multicolumn{2}{|l|}{$\begin{array}{l}\text { General trust towards others } \\
\text { - baseline level: yes }\end{array}$} \\
\hline no & $-0.77(0.25)^{* * *}$ \\
\hline \multicolumn{2}{|l|}{$\begin{array}{l}\text { Trust towards lending entities } \\
\text { - baseline level: yes }\end{array}$} \\
\hline no & $-0.54(0.22)^{* *}$ \\
\hline \multicolumn{2}{|l|}{$\begin{array}{l}\text { Seeking information from family } \\
\text { - baseline level: no }\end{array}$} \\
\hline yes & $-1.71(0.38)^{* * *}$ \\
\hline $\mathrm{AIC}$ & 589.48 \\
\hline $\mathrm{BIC}$ & 638.60 \\
\hline Numbers of observations & 1,004 \\
\hline
\end{tabular}

Notes: ${ }^{* * *} \mathrm{p}<0.01,{ }^{* *} \mathrm{p}<0.05,{ }^{*} \mathrm{p}<0.1$

Source: Authors 


\begin{tabular}{|l|c|}
\hline & $\begin{array}{c}\text { Model of trust towards } \\
\text { credit unions }\end{array}$ \\
\hline (Intercept) & $\mathbf{0 . 8 3}(0.13)^{* * * *}$ \\
\hline $\begin{array}{l}\text { Previous customer experience with credit unions } \\
\text { - baseline level: no }\end{array}$ & $\mathbf{1 . 3 2}(0.46)^{* * *}$ \\
\hline 1 - yes & \\
\hline $\begin{array}{l}\text { General trust towards others } \\
\text { - baseline level: yes }\end{array}$ & $-\mathbf{0 . 3 1}(0.13)^{* * *}$ \\
\hline 2 - no & \\
\hline $\begin{array}{l}\text { Trust towards lending entities } \\
\text { - baseline level: yes }\end{array}$ & \\
\hline 3 - no & $-\mathbf{0 . 6 5}(0.14)^{* * *}$ \\
\hline AIC & $1,336.78$ \\
\hline BIC & $1,356.43$ \\
\hline Numbers of observations & 1,004 \\
\hline
\end{tabular}

Notes: ${ }^{* * *} p<0.01,{ }^{* *} p<0.05,{ }^{*} p<0.1$

Source: Authors

\begin{tabular}{|l|c|c|}
\hline Statistically significant coefficients in the model & Odds ratio & p-value \\
\hline $\begin{array}{l}\text { Previous customer experience with credit unions: yes } \\
\text { - baseline level: no }\end{array}$ & 3.75 & 0.004 \\
\hline $\begin{array}{l}\text { General trust towards others: no } \\
\text { - baseline level: yes }\end{array}$ & 0.74 & 0.021 \\
\hline $\begin{array}{l}\text { Trust towards lending entities: no } \\
\text { - baseline level: yes }\end{array}$ & 0.52 & 0.000 \\
\hline
\end{tabular}

Source: Authors 


\begin{tabular}{|c|c|}
\hline & $\begin{array}{l}\text { Model of trust towards loan } \\
\text { companies / traditional segment }\end{array}$ \\
\hline (Intercept) & $-0.72(0.44)^{*}$ \\
\hline \multicolumn{2}{|l|}{ Objective knowledge } \\
\hline plus one score in the test & $-0.07(0.03)^{* *}$ \\
\hline \multicolumn{2}{|l|}{$\begin{array}{l}\text { Educational attainment } \\
\text { - baseline level: secondary education }\end{array}$} \\
\hline primary education & $0.38(0.41)$ \\
\hline vocational education & $0.07(0.26)$ \\
\hline higher education & $0.59(0.20)^{* * *}$ \\
\hline Ph.D. & $0.62(0.38)$ \\
\hline \multicolumn{2}{|l|}{$\begin{array}{l}\text { Place of living } \\
\text { - baseline level: village }\end{array}$} \\
\hline town: up to 49,999 residents & $0.20(0.24)$ \\
\hline town: from 50,000 to 99,999 residents & $0.51(0.28)^{*}$ \\
\hline town: from 100,000 to 499,999 residents & $0.51(0.26)^{* *}$ \\
\hline city: 500,000 residents or more & $0.19(0.25)$ \\
\hline \multicolumn{2}{|c|}{$\begin{array}{l}\text { Previous customer experience with loan companies from } \\
\text { traditional segment } \\
\text { - baseline level: no }\end{array}$} \\
\hline yes & $1.61(0.56)^{* * *}$ \\
\hline \multicolumn{2}{|l|}{$\begin{array}{l}\text { Considering initial loan processing payment } \\
\text { - baseline level: yes }\end{array}$} \\
\hline no & $-1.13(0.40)^{* * *}$ \\
\hline it depends & $-0.48(0.42)$ \\
\hline \multicolumn{2}{|l|}{$\begin{array}{l}\text { Trust towards lending entities } \\
\text { - baseline level: yes }\end{array}$} \\
\hline no & $-0.85(0.17)^{* * *}$ \\
\hline \multicolumn{2}{|l|}{$\begin{array}{l}\text { Seeking information from the Internet } \\
\text { - baseline level: no }\end{array}$} \\
\hline yes & $0.58(0.18)^{* * *}$ \\
\hline $\mathrm{AIC}$ & 951.58 \\
\hline $\mathrm{BIC}$ & $1,025.26$ \\
\hline Numbers of observations & 1,004 \\
\hline
\end{tabular}

Notes: ${ }^{* *} \mathrm{p}<0.01,{ }^{* *} \mathrm{p}<0.05,{ }^{*} \mathrm{p}<0.1$

Source: Authors 


\begin{tabular}{|l|c|c|}
\hline Statistically significant coefficients in the model & Odds ratio & p-value \\
\hline Objective knowledge: plus one score in the test & 0.93 & 0.022 \\
\hline $\begin{array}{l}\text { Educational attainment: higher education } \\
\text { - baseline level: secondary education }\end{array}$ & 1.80 & 0.004 \\
\hline $\begin{array}{l}\text { Place of living: town: from 50,000 to 99,999 residents } \\
\text { - baseline level: village }\end{array}$ & 1.66 & 0.068 \\
\hline $\begin{array}{l}\text { Place of living: town: from 100,000 residents to 499,999 } \\
\text { residents } \\
\text { - baseline level: village }\end{array}$ & 1.67 & 0.049 \\
\hline $\begin{array}{l}\text { Previous customer experience with loan companies from } \\
\text { traditional segment: yes } \\
\text { - baseline level: no }\end{array}$ & 5.03 & 0.004 \\
\hline $\begin{array}{l}\text { Considering initial loan processing payment: no } \\
\text { - baseline level: yes }\end{array}$ & 0.43 & 0.005 \\
\hline $\begin{array}{l}\text { Trust towards lending entities: no } \\
\text { - baseline level: yes }\end{array}$ & 1.79 & 0.001 \\
\hline $\begin{array}{l}\text { Seeking information from the Internet: yes } \\
\text { - baseline level: no }\end{array}$ & & 0.000 \\
\hline
\end{tabular}

Source: Authors

\begin{tabular}{|l|c|c|}
\hline Statistically significant coefficients in the model & Odds ratio & p-value \\
\hline $\begin{array}{l}\text { Age: from } 21 \text { to } 40 \\
\text { - baseline level: from } 18 \text { to } 21 \text { years }\end{array}$ & 0.55 & 0.088 \\
\hline $\begin{array}{l}\text { Age: from } 41 \text { to } 50 \\
\text { - baseline level: from } 18 \text { to } 21 \text { years }\end{array}$ & 0.49 & 0.054 \\
\hline $\begin{array}{l}\text { Age: from } 51 \\
\text { - baseline level: from 18 to } 21 \text { years }\end{array}$ & 0.46 & 0.022 \\
\hline $\begin{array}{l}\text { Place of living: city: } 500,000 \text { residents or more } \\
\text { - baseline level: village }\end{array}$ & 0.62 & 0.033 \\
\hline $\begin{array}{l}\text { Previous customer experience with loan companies } \\
\text { from online segment: yes } \\
\text { - baseline level: no }\end{array}$ & 0.44 & 0.000 \\
\hline $\begin{array}{l}\text { Trust towards lending entities: no } \\
\text { - baseline level: yes }\end{array}$ & 1.53 & 0.03 \\
\hline $\begin{array}{l}\text { Seeking information from the Internet: yes } \\
\text { - baseline level: no }\end{array}$ & 0.007 \\
\hline
\end{tabular}

Source: Authors 


\begin{tabular}{|c|c|}
\hline & $\begin{array}{l}\text { Model of trust towards loan } \\
\text { companies / online segment }\end{array}$ \\
\hline (Intercept) & $-0.15(0.35)$ \\
\hline \multicolumn{2}{|l|}{$\begin{array}{l}\text { Age } \\
\text { - baseline level: from } 18 \text { to } 21 \text { years }\end{array}$} \\
\hline from 22 to 30 & $-0.48(0.36)$ \\
\hline from 31 to 40 & $-0.60(0.35)^{*}$ \\
\hline from 41 to 50 & $-0.72(0.37)^{*}$ \\
\hline from 51 & $-0.78(0.34)^{* *}$ \\
\hline \multicolumn{2}{|l|}{$\begin{array}{l}\text { Place of living } \\
\text { - baseline level: village }\end{array}$} \\
\hline town: up to 49,999 residents & $-0.04(0.20)$ \\
\hline town: from 50,000 to 99,999 residents & $0.01(0.25)$ \\
\hline town: from 100,000 citizens to 499,999 residents & $-0.06(0.23)$ \\
\hline city: 500,000 residents or more & $-0.47(0.22)^{* *}$ \\
\hline \multicolumn{2}{|l|}{$\begin{array}{l}\text { Previous customer experience with loan companies } \\
\text { from online segment } \\
\text { - baseline level: no }\end{array}$} \\
\hline yes & $1.49(0.40)^{* * *}$ \\
\hline \multicolumn{2}{|l|}{$\begin{array}{l}\text { Trust towards lending entities } \\
\text { - baseline level: yes }\end{array}$} \\
\hline no & $-0.46(0.15)^{* * *}$ \\
\hline \multicolumn{2}{|l|}{$\begin{array}{l}\text { Seeking information from the Internet } \\
\text { - baseline level: no }\end{array}$} \\
\hline yes & $0.42(0.16)^{* * *}$ \\
\hline AIC & $1,144.14$ \\
\hline $\mathrm{BIC}$ & $1,203.08$ \\
\hline Numbers of observations & 1,004 \\
\hline
\end{tabular}

Notes: ${ }^{* * *} \mathrm{p}<0.01,{ }^{* *} \mathrm{p}<0.05,{ }^{*} \mathrm{p}<0.1$

Source: Authors 
Tables A2 | Multivariate Linear Regression Results

\begin{tabular}{|c|c|}
\hline & $\begin{array}{l}\text { Model of objective } \\
\text { knowledge scores }\end{array}$ \\
\hline (Intercept) & $-2.77(0.50)^{* * * *}$ \\
\hline \multicolumn{2}{|l|}{$\begin{array}{l}\text { Gender } \\
\text { - baseline level: female }\end{array}$} \\
\hline male & $0.35(0.17)^{* * *}$ \\
\hline \multicolumn{2}{|l|}{$\begin{array}{l}\text { Educational attainment } \\
\text { - baseline level: secondary }\end{array}$} \\
\hline primary & $0.26(0.41)$ \\
\hline vocational & $-0.33(0.24)$ \\
\hline higher & $1.00(0.20)^{* * *}$ \\
\hline Ph.D. & $1.42(0.40)^{* * * *}$ \\
\hline \multicolumn{2}{|c|}{$\begin{array}{l}\text { Net income per family member } \\
\text { - baseline level: from PLN } 500 \text { to } 999\end{array}$} \\
\hline under PLN 500 & $0.67(0.38)^{*}$ \\
\hline from PLN 1,000 to 1,499 & $0.36(0.27)$ \\
\hline from PLN 1,500 to 1,999 & $0.73(0.28)^{* * * *}$ \\
\hline from PLN 2,000 to 2,499 & $0.81(0.36)^{* * *}$ \\
\hline from PLN 2,500 to 2,999 & $1.62(0.37)^{* * * *}$ \\
\hline PLN 3,000 or more & $1.00(0.32)^{* * * *}$ \\
\hline refused to answer & $1.01(0.28)^{* * * *}$ \\
\hline \multicolumn{2}{|c|}{$\begin{array}{l}\text { Do opinions of others influence your choices of lending entities? } \\
\text { - baseline level: yes }\end{array}$} \\
\hline no & $0.33(0.17)^{*}$ \\
\hline \multicolumn{2}{|l|}{$\begin{array}{l}\text { Do you generally trust others? } \\
\text { - baseline level: yes }\end{array}$} \\
\hline no & $-0.44(0.17)^{* * *}$ \\
\hline \multicolumn{2}{|c|}{ How much do you trust loan companies? } \\
\hline numeric scale from 1 to 5 & $-0.24(0.12)^{* * *}$ \\
\hline \multicolumn{2}{|c|}{$\begin{array}{l}\text { What is your general attitude towards loans? } \\
\text { - baseline level: decidedly positive }\end{array}$} \\
\hline rather positive & $0.36(0.44)$ \\
\hline moderate & $0.59(0.42)$ \\
\hline rather negative & $1.09(0.45)^{* *}$ \\
\hline decidedly negative & $0.99(0.45)^{* *}$ \\
\hline AIC & $4,774.41$ \\
\hline $\mathrm{BIC}$ & $4,877.55$ \\
\hline Numbers of observations & 1,004 \\
\hline
\end{tabular}

Notes: ${ }^{* * *} p<0.01,{ }^{* *} p<0.05,{ }^{*} p<0.1$

Source: Authors

Objective knowledge test scores is the explained variable in the model. Bold font style marks statistically significant coefficients. The levels of significance are marked with asterisks. Standard errors of the coefficients are in parenthesis. 


\section{References}

Atkinson, A., Messy, F. (2012). Measuring Financial Literacy: Results of the OECD / International Network on Financial Education (INFE) Pilot Study. Organisation for Economic Co-operation and Development. OECD Working Papers on Finance, Insurance, and Private Pensions No. 15. OECD Publishing, http://dx.doi.org/10.1787/5k9csfs90fr4-en

Bialowolski, P. (2012). Rynek firm pozyczkowych w Polsce. Charakterystyka sektora i profil klienta. (The Market of Personal Loan Companies in Poland. Sector Characteristics and Profile of the Client). Warsaw: Konfederacja Przedsiębiorstw Finansowych w Polsce. Retrieved from: http://www.senat.gov.pl/gfx/senat/userfiles/_public/k8/komisje/2012/kbfp/ materialy/47pospozy.pdf

Central Statistical Office (2014). Monitoring of Banks. Warsaw: Central Statistical Office.

Ciesla, S. (2014). Charakterystyka polskiego rynku pozyczek pozabankowych w kontekscie propozycji niektorych zmian ustawowych. (The Characteristics of Polish Market for Non-Banking Loans in the Context of Some Statutory Amendments Proposition). Retrieved from: https://legislacja.rcl.gov.pl/docs//2/262790/262809/dokument148103.pdf

Credit Information Bureau \& The Kronenberg Foundation (2014). Wiedza o produktach kredytowych i wiarygodnosci finansowej w percepcji Polakow. (The Knowledge on Credit Facilities and Credit Worthiness as Perceived by Poles).Warsaw: the Credit Information Bureau and the Kronenberg Foundation.

Czapinski, J., Panek, T. (2015). Diagnoza spoleczna 2015. Warunki i jakosc zycia Polakow (Social Diagnosis 2015. Poles' Conditions and Quality of Living.).Warsaw: Rada Monitoringu Społecznego.

Deutsche Bank (2013). Raport: Portret finansowy Polki 2013. (Report: Financial Portrait of Polish Woman).Warsaw: Deutsche Bank.

Disney, R., Gathergood, J. (2011). Financial Literacy and Indebtedness: New Evidence for U.K. Consumers. University of Nottingham. Centre for Finance, Credit and Macroeconomics. Working Paper No. 11/05, https://doi.org/10.2139/ssrn.1851343

Fundacja Republikanska (2013). Problematyka regulacji rynku firm pożyczkowych w Polsce. (The Issue of Regulation on the Market for Personal Loans in Poland).Warsaw: 2013.

ING (2013). Finansowy Barometr ING: Miedzynarodowe badanie ING na temat postaw konsumentow wobec finansow, mediow społecznosciowych oraz bankowosci mobilnej w Polsce i na swiecie. (ING Financial Barometer: International Study of Consumers' Attitudes to Finance Issues, Social Media and Mobile Banking in Poland and Worldwide). Retrieved from: http://media.ingbank.pl/pr/246004/media-spolecznosciowe-istotne-przypodejmowaniu-decyzji-finansowych-wynika-z-miedzynarodowego-badania-ing

Instytut Wolnosci \& Raiffeisen Polbank (2014). Stan wiedzy ekonomicznej Polakow. (Economic Literacy of Poles).Warsaw: Instytut Wolnosci \& Raiffeisen Polbank.

Kaczmarski, P. (2015). Rynek w swietle planowanej nowelizacji Ustawy o nadzorze nad rynkiem finansowym (Financial Market in the Light of Planned Regulation Act). Gazeta Finansowa. No. 31/32, 18.

Lusardi, A., Tufano, P. (2009). Debt Literacy, Financial Experiences, and Overindebtedness. National Bureau of Economic Research. Working Paper No. 14808, https://doi.org/10.3386/w14808

Luczak, K. (2015). Rynek pozyczkowy dojrzal do regulacji (Personal Lending Market Matured for Regulation). Gazeta Finansowa. No. 31/32, 19. 
National Bank of Poland (2012). Komunikat Komitetu Stabilnosci Finansowej. Ustalenia KSF i rekomendowane dzialania w odniesieniu do instytucji parabankowych. (Financial Stability Committee's Statement. Arrangements and Recommended Actions in Relation to Parabanks). Retrieved from: http://www.nbp.pl/home.aspx?f=/aktualnosci/ wiadomosci_2012/20120816_kom.html

National Bank of Poland (2015). Sytuacja finansowa sektora gospodarstw domowych w V kw. 2014 r. (Financial Situation of Households in Fourth Quarter of 2014).Warsaw: National Bank of Poland.

PwC (2013). Personal Loans Market in Poland. Warsaw: PwC.

Szelagowska, A. (2015). Rynek pozyczek pozabankowych w Polsce w swietle polityki niskich stop procentowych banku centralnego. (Polish Market for Non-Banking Loans in the Light of low Interest Rates Policy of Central Bank). Kwartalnik Kolegium EkonomicznoSpolecznego. Studia i Prace, 1(3), 119-136.

The Office of Competition and Consumer Protection (2012). Konsument na rynku uslug finansowych. (Consumer on the Market for Financial Services).Retrieved from: https:// uokik.gov.pl/download.php?plik=12138

The World Bank (2014). Financial Inclusion. Washington: The World Bank.

Zwiazek Firm Pozyczkowych (2013). Mikropozyczki w Polsce. (Microloans in Poland).Warsaw: Zwiazek Firm Pozyczkowych.

Zwiazek Przedsiebiorcow i Pracodawcow (2015). Walka o polski rynek pozyczkowy w swietle nowelizacji Ustawy o kredycie konsumenckim. (The Struggle for Polish Lending Market in the Light of Consumer Credit Act Amendment).Warsaw: Związek Przedsiebiorcow i Pracodawcow. 